\title{
6. 'All our strength, all our kindness and our love': Bertha McNamara, bookseller, socialist, feminist and parliamentary aspirant
}

\author{
Michael Richards ${ }^{1}$
}

In the foyer of Trades Hall, Sydney, there is a brass plaque with an image of a woman. The inscription on it reads:

Bertha McNamara

kindly and gracious in her splendid way

She knew no nationhood

And her religion each and every day

Was that of doing good.

Jammed up against it when I last visited was a fire hose reel.

Who was Bertha McNamara? A memorial notice printed after her death in 1931 called her 'The Mother of the Australian Labor Movement' and Labor's 'Grand Old Lady', mentioned that she was the mother-in-law of Jack Lang and Henry Lawson, and that she had a faith in socialism, which she was accustomed to proclaim at Labor Party conferences. She is still around on the edge of public memory. There is an entry in the Australian Dictionary of Biography, and once there was a hostel named after her in Sydney. A few people have written about her and a search on Google turns up a handful of hits. She has a stub on Wikipedia.

There should be more. In her militant challenges to parliamentary Labor, in her work as a radical bookseller and proprietor of a socialist reading room, and in her own political writing, she was one of the early shapers of the Australian labour movement. And if she had succeeded in winning Australian Labor Party (ALP) preselection for the Senate in New South Wales in 1928, she might have become the first woman in the Australian Commonwealth Parliament. ${ }^{2}$ When

1 The Museum of Australian Democracy at Old Parliament House.

2 And she might have won, if she had been in the top three on the ALP ticket. After a strong campaign in New South Wales, Labor won all three senate seats up for election at the 1928 half-senate election in that State, defeating two incumbent opponents. Overall, the Nationalists and the Country Party easily maintained 
she stood for preselection, a year after parliament moved to Canberra and the building now known as Old Parliament House, women had won the right to sit in parliament in only 11 nations in the world but nine of them had already elected women. ${ }^{3}$ Although 26 Australian women had stood for election between their national enfranchisement in 1903 and 1943, when the first women were elected, none of them was endorsed by a major party. McNamara was to be no exception. ${ }^{4}$

Indeed, McNamara's path exemplifies much of the Australian feminist experience in the nineteenth and early twentieth centuries. An immigrant who encountered hard times and who for some years could only focus on personal and family survival, she developed as a leader within Australian socialism in the roles of writer, facilitator and networker. Her leadership was as one who influences others, both directly, through her own views, and indirectly, making the views of other change-makers available to men and women with little access through other means to a world of radical alternatives. Her trajectory reminds us that although the early Australian labour movement was strongly characterised by masculine privilege, activist women were vital to its success but at lower levels in the hierarchy. Late in her life, when she advocated an avowedly feminist claim to parliamentary leadership, she was soundly rejected by her party. Although this was a defeat, followed quickly by her death, an appreciation of her life should acknowledge that she was one of the pioneers for the achievements of Australian women leaders in later years.

The broad facts of Bertha McNamara's life can be gleaned from Verity Burgmann's entry for her in the Australian Dictionary of Biography. To paraphrase: Matilda Emilie Bertha Kalkstein (1853-1931) was born at Posen, then part of Prussia. She immigrated to Victoria in 1869 after economic difficulties broke up the family home. There she lived at Bairnsdale, working as governess for an aunt, and in 1872 married Peter Hermann Bredt, a Prussian-born accountant who was the shire secretary. They had six children who lived, and three who died in infancy. In 1888 Bredt died; Bertha was left almost penniless. She moved to Melbourne and worked as a travelling saleswoman, selling jewellery and sewing machines. In 1892 she married William Henry McNamara, who had in 1887 been one of the founders of the Australian Socialist League but who had left it the year before in protest against its decision to support the new Labor Electoral League

control of the 36-member senate, and the Bruce-Page conservative government was returned to office, but Labor's strong result in New South Wales heralded Scullin's landslide win in the House of Representatives election the following year.

3 Government of Australia, Women in the Senate, Senate Brief 3 (Canberra: Department of the Senate, April 2014), 6, http://www.aph.gov.au/About_Parliament/Senate/Powers_practice_n_procedures/Senate_Briefs/ Brief03.

4 I gratefully acknowledge the warm courtesy of Bertha McNamara's granddaughter, Margaret Bertha McNamara Henry, and her daughter, Lyndal Gaines, both of Brisbane, in providing invaluable assistance in telling this story. 
and reformist state socialism. A powerful orator and experienced political organiser, four years younger than his wife, he was Australian born and had been politically active since the mid 1880s. In 1893 the McNamaras opened a bookshop in Castlereagh Street, Sydney, where Bertha also ran a boarding house and to which was adjoined the Socialist Reading Room. In the 1890s she was a leading member of the Social Democratic Federation of Australasia and of the Womanhood Suffrage League of New South Wales. She was a founding member of the Labor Women's Central Organising Committee and a frequent delegate to State Labor conferences. After William's death in 1906, she ran the bookshop on her own, maintaining it in various locations until 1929. The shop was a crucial meeting place for Sydney's left for all of its history. In the 1890s, Verity Burgmann records:

The back room and the reading room above the shop were scenes of almost constant activity and discussion by socialists, feminists, anarchists, rationalists, Laborites and literary Bohemians ... During World War I the shop was more than ever in demand as an organizing centre for radical activity. Bertha assisted in many ways, especially by selling banned anti-militarist literature.

She died in 1931, after catching a chill in the Sydney Domain, where she had gone to speak against her one-time friend Adela Pankhurst. The former suffragette and socialist had turned in recent years against the causes she and Bertha had once held dear. Now an advocate of industrial peace and fiercely anticommunist, Adela Pankhurst was simply the latest in a long line of deserters from the working-class movement that Bertha McNamara believed in, and against whom she battled for 40 years. ${ }^{5}$

What can we find of Bertha McNamara beyond this? She was a prolific letter writer, writing dozens of letters to the labour press, especially Labor Daily in the 1920s. She wrote several pamphlets herself, one of them probably the first published work on Australian socialism by a woman. The bookshop she and her husband ran, along with its Socialist Reading Room, is mentioned in some ephemeral material. There is anecdotal evidence relating to her in accounts of the great names she was associated with, especially Jack Lang, who was said to be terrified of her, especially when she led a delegation of Labor women to the premier's office. There are family papers in the State Library of New South Wales, and a small collection of letters and other manuscripts in H. V. 'Doc' Evatt's papers, held by Flinders University Library in Adelaide. These

5 Verity Burgmann, 'McNamara, Matilda Emilie Bertha (1853-1931)', in Australian Dictionary of Biography Online (Canberra: National Centre of Biography, The Australian National University), http://adb.anu.edu.au/ biography/mcnamara-matilda-emilie-bertha-7431/text12935, and 'McNamara, William Henry (1857-1906)', in Australian Dictionary of Biography Online (Canberra: National Centre of Biography, The Australian National University), http://adb.anu.edu.au/biography/mcnamara-william-henry-7432/text12937. 
two folders of scorched, fire-damaged papers include also a few papers of her husband's, and letters to both of them, along with a tally of letters to the press by her published in the 1920s. ${ }^{6}$ In what follows I draw primarily on these two folders, which I encountered when researching a National Library of Australia exhibition in the early 1990s.

The letters are strong evidence of her role as a networker. For example, in 1927 Mary Hoolahan of Orange, to the west of Bathurst in New South Wales, wrote to her:

You see, I am cut off from Orange + Molong chiefly by my children, + like to be in it all the same when the class war is on. G. K Chesterton says looking after one child 'is an all-time job'-Bernard Shaw responds 'What about six?' Well I have 7 and no school for them + no help. My neighbour has 1 only and a trained nurse for it, a servant, a cool house and 2 cars, etc. etc., etc. All of us have a small tin shack, or not much better. Well, they are kind to us-but why should moneyed people usurp the joys of giving along with most other things? Even affection is wrested from the poor, for love cannot flourish in dirt and want and with harried tempers - ugliness bred of being overtaxed for generations. Greed and dishonesty and hatred and uncouthness batten on the feelings of the poor ... If people think that slavery went out with the traders they are blind. The chief difference is that, whereas in past days slaves + their families had to be fed + clothed + housed, at the present time they are free only to leave-then they must provide for themselves + their numerous families ...

If you know where I can procure the writings of the late Louisa Lawson I would be so grateful if you let me know as I am most anxious to get hold of some of them.

Yours in all sisterly feelings, dear Comrade, Mary Hoolahan. ${ }^{7}$

Testimony to the importance of McNamara as both bookseller and political correspondent to her clients, such letters show she was a key point of contact with the world of ideas and books for some of like mind in rural Australia. ${ }^{8}$

\footnotetext{
6 It is possible Evatt was planning a book, some posthumous memorial or collection of her writings, which was never completed. He was at school with her youngest son, William, who was active in the Socialisation Movement in the NSW Labor Party in the late 1920s, and perhaps the son acted as a conduit for the papers: the McNamara and Evatt families remained close friends for many years. Personal communication from Margaret Henry, Bertha's granddaughter, 2011.

7 'Mary Hoolahan to Bertha McNamara', 19 March 1927, Evatt Collection, Special Collections, Flinders University Library, Adelaide [hereinafter Evatt Collection].

8 This letter was written at the time of a struggle for control of the upper house of the NSW legislature, the Legislative Council, at a time when that body was appointed by the governor and not elected. Mary Hoolahan
} 
An earlier group of letters reflects the rivalries of the tiny socialist groups of the period. These are from A. R. Jutson to both Bertha and William McNamara, written in the 1890s from Bourke, in the far north-west of New South Wales. Jutson had been an ally in the Australian Socialist League, but had left it. ${ }^{9} \mathrm{He}$ worked as a station schoolmaster, and McNamara's bookshop clearly was his lifeline to a world of ideas and books. Writing in 1891 about the Australian Socialist League, he urges:

As regards the League, I say come out from it: have nothing to do with the unclean thing. Gather a nucleus of real earnest genuine socialists, with brains in their heads; and honesty and truth-feelings in their hearts, and so start afresh in our sacred cause ... Recollect, that we are men, brave men and not cowards, fleeing before a revolution, but leaders, guides, redeemers and benefactors, and so let us charge cheerfully and undaunted by all shams and semblances and advance spiritedly on hypocrisy and ignorance, on chaos and the dark. ${ }^{10}$

And in 1894:

The mad ways of the Trades-unions have disgusted me, and I am losing the faith I once had in their being of use, when we should need them in the fateful hour which is to come ... Knaves win in the political struggle; and the honest and just man is defeated. Society seems to be delivered over from the hands of one set of criminals into the hands of another set of criminals as often as the government is changed ... Politics is worth earnest study and earnest endeavour, provided that we mean the word to stand for what it once stood for - an application of the principles on which all our social and political action should be founded: namely the great principles of Justice, Truth, and Catholicity, aided by the great truths of what we now call Social Science ... Politics has come to mean the crafty management of a political party by caucuses, and all sorts of trickery and finesse in the contests for political power and emolument. ${ }^{11}$

In 1892 the McNamaras too left the Australian Socialist League ${ }^{12}$ to found the Social Democratic Federation of Australasia (SDF). In terms strongly reminiscent of Bertha's writing, its 1895 manifesto proclaimed:

\footnotetext{
is remembered by her daughter-in-law as a friend of Mary Gilmore and a committed supporter of Jack Lang. She was widowed later that year, left the land (she and her husband had sharefarmed), returned to Sydney and later taught. Personal correspondence with the Hoolahan family, 1998.

9 Jutson was close enough to the McNamaras that they named their son Bill (William Morris Jutson McNamara 1893-?) after him as well as William Morris. They had two children, Bill and Alice, and Bertha brought six children to the family from her first marriage, including Bertha and Hilda.

10 'A. R. Jutson to W. H. McNamara', 28 December 1891, Evatt Collection.

11 'A. R. Jutson to W. H. \& B. McNamara', 8 August 1894, Evatt Collection.

12 The tiny Australian Socialist League struggled with the problem of what to do about the purity of socialist thought in the face of the modest electoral success of the Labor Electoral Leagues and the growing interest a
} 
The concentration of wealth in the hands of a few non-producers, and the alarming increase of poverty among the workers in every civilised country, is the problem of the age ... The workers of bankrupt, taxridden countries are only held in check by the bayonet and artillery controlled by nation-pillagers who masquerade as financiers and statesmen ... In Australia the worker is economically reduced to a condition of serfdom ... The increase of labour-displacing machinery renders the obsolete methods of trade unionism powerless to cope with the power of organised capitalism, and the strike as a means of attack (unless universal) ends in the starvation of those who engage in it.

The federation was launched at the second of two inter-colonial congresses of Australian socialists at Leigh House in Sydney in November 1893, which called for 'the complete abolition of the private ownership of the means of production, distribution, and exchange', and it represented itself as the face of Australian socialism at the Zurich Socialist and Labour Congress of 1893, the third congress of the Second International. ${ }^{13}$

In Australia in these years, the parliamentary Labor movement was going through with its first split, which followed the dramatic emergence of political Labor as a parliamentary force in New South Wales in 1891 and which reflected the ebb and flow of opinion among Australian socialists of the time about the role of parliament. Not all Labor MPs were socialists, and many socialists were dubious of the new Labor parties. The refusal by most of the original 35 Labor parliamentarians to accept caucus control of their votes and a tightened pledge demonstrates how completely they accepted the concept of representative democracy, at least after winning their seats in parliament. Jutson and the McNamaras were not alone in denouncing them as rats. For them, the breakthrough of 1891-hailed in 1991 as the birth of a century-old tradition of Labor in politics - was simply the beginning of another failure, to be set alongside the failure of the unions in the strikes of 1890 and 1891 .

number of socialist leaders therefore had in the parliamentary process throughout the 1890s. Initially, 'quarter philosophical anarchist, quarter physical-force anarchist, quarter state socialist, and quarter laborite', in the words of one of its founders, T. Batho, the anarchists had left by 1890 and the Labor parliamentarians, among them W. M Hughes and W. A. Holman, by 1897. In that year the league adopted a new manifesto and decided to run its own candidates at future elections, and in 1898 it required its members to resign from any other political organisation, long before Labor introduced the same principal. Ian Turner argues that the ambivalence evident in the ASL's history in the 1890s was common to every socialist group active in Australian politics. How could revolutionary ideals and dreams be reconciled with the desperate need for reforms that were perhaps achievable through parliament, at least in part? Ian Turner, Industrial Labor and Politics (Canberra: ANU Press, 1965), 28-9.

13 W. H. Mellor [Secretary], Manifesto of the Social Democratic Federation of Australasia (Sydney: The Federation, 1895), MS 9547, Box 1268/5, State Library of Victoria, Melbourne, http://www.reasoninrevolt. net.au/biogs/E000042b.htm. 
As has been well documented, labour activist responses were many. ${ }^{14}$ Some, including William Lane and Mary Gilmore, took refuge in foreign utopianism, attempting to establish a cooperative settlement in Paraguay. E. J. Banfield retreated within Australia, finding a refuge from political disillusion in a life as an island beachcomber, gardener and writer on Dunk Island, in far north Queensland. Others sought ideological purity within the tiny splinter parties and movements of the left, or opted to stay within the Labor Party and attempt to keep alive the principles of socialism within an increasingly non-socialist party. Bertha McNamara was in the end one of these. By the end of the first decade of the twentieth century she was a socialist activist within the Labor Party, suspicious of its parliamentary members but, almost at the end of her life, herself a candidate for the Australian Senate. Untangling her political trajectory in the 1890s and then after the formation of the SDF is at times a difficult task. One way of doing it is through her writing.

The pamphlet Home Talk on Socialism and the Redemption of the World's Labourers, published in Hobart in 1891 under the anonymous authorship of 'A Woman', was her first known publication. It was also one of the very first books or pamphlets espousing socialism to be published in Australia, and was published soon after she had become actively involved in radical politics. Only one copy is known to survive in a public collection, in the Mitchell Library in Sydney. In this, as in so many other respects, McNamara's fragile documentary record epitomises the vulnerability and near-invisibility of so much feminist history. In 20 years of searching, I have never found another copy: if not for this library copy, the nature of her first-known publication might have been lost forever.

The pamphlet is short, only nine pages, and written in a terse, direct style. 'The misery of our social life', she begins, 'who can see, hear and read about it, and not be moved to use their utmost endeavours to aid in a reform for the better' ${ }^{15}$ She tells of a mansion close by: 'Even from where I am writing I can see a grand palatial residence, the beautiful grounds whereon it stands are sloping right down to a lovely river bank, with the mild autumn sun shining upon it - Eden itself could scarce have looked fairer.' ${ }^{16}$ But:

[T] he mansion is shut up, no one remains but a caretaker and a gardener somewhere located in the back premises. Its owner has gone to live in another beautiful mansion near a large city, where he and his family can enjoy the gaiety of the winter season. He soweth not, neither

14 See, for example, Verity Burgmann, 'In Our Time': Socialism and the Rise of Labor, 1885-1905 (Sydney: George Allen \& Unwin, 1985).

15 [Bertha McNamara], Home Talk on Socialism, and the Redemption of the World's Labourers (Hobart: Calder, Bowden \& Co., 1891), 1.

16 Ibid., 6-7. 
does he reap, neither does he make himself otherwise useful, he is an independent gentleman of a large fortune. Only a short distance from this beautiful mansion, are a number of small cottages, more or less in preservation, mostly less, here the labourers live with their families, the men who toil, who sow, and who reap, to provide the rich man and his kindred with bread; the men who, to the best of their strength and ability, do their share of life's labour. Here they live, with wife and children, huddled together in a few small rooms, and even these are the rich man's property. ${ }^{17}$

She writes of the shearers' strike in Queensland, where working men 'after trying in vain all means of peaceful cohesion ... have gone out on strike to take back by force and open warfare what others have taken from them and are keeping from them, by stealth and stratagem'. However:

Government under the control of Capital has, under the plea of keeping law and order, sent out its soldiery to aid one section of the community against the other ... [and] comes the shameful report, which, if true, must make every patriotic Australian blush. We, who have so recently been shocked, and protested against half-civilized Russia's cruel treatment of its prisoners; we, who read with shudders of the atrocities committed in the penal regime of Van Dieman's Land-we read, in our year of grace, that the Shearer's Union strike leaders are chained to each other, to prevent escape, on their way to prison. Once again, who would not be a Socialist, and help with might and strength to build a social structure where strife and fighting would cease. ${ }^{18}$

McNamara cites Edward Bellamy's novel Looking Backward twice in this 1891 pamphlet, once as an example of a 'perfected human society' and once as a warning that under capitalism even the rich are not exempt from the prospect of loss and pain. Bellamy's utopian socialist novel, first published in the United States in 1888, had a wide influence on Australian radical thought. McNamara may have read the edition published by E. W. Cole in Australia in 1888 or 1889 or read the version serialised by William Lane in The Worker in $1890 .{ }^{19}$ Bellamy's portrait of a society in which human goodness is allowed to flourish and such traits as crime and aggression disappear simply because there is no need for them once inequality and poverty have been overcome is strongly reminiscent of the tone of McNamara's pamphlet. ${ }^{20}$

17 Ibid., 7.

18 Ibid., 8.

19 Looking Backwardwas published again in Melbourne by Cole in 1920, by Andrade's Bookshop in the 1920s, in a braille edition in 1925 and in Sydney in 1932 by the socialist activist E. E. Judd, who reissued it in 1942 and 1943 under the imprimatur of the Socialist Labor Party of Australia, along with its sequel, Equality. 20 Bellamy's influence on working-class readers in Australia is further attested to by T. A. Coghlan, writing in 1918: '[In Australia] the workers are a reading class and Bellamy's solution of the problem of living, his 
An unpublished short story by McNamara turns on another socialist classic of the times, and was perhaps written in the mid or late 1890s. Arthur Richmond begins work in an English textile factory when he is twelve. He invents a device that improved the machines: being too poor to patent it himself, he trusts his employer with the idea, and has it stolen from him. But it does result in a transfer to the engineering workshop, where he can explore his mechanical genius. He invents another device, which will automate part of the weaving process, but decides to keep it to himself. And he has fallen in love with the girl next door: she will not have to slave as his parents had, once his invention is completed. Then a stranger comes to town and holds a great meeting in the market square. This is his message:

Machinery is everywhere replacing human labour, in the workshops, in the fields, in the factories. The workers are told they must go, there is no work for them and strong men look aghast and tired weary women look white with fear and the little children are crying for bread. And where do they go to these starving unfortunates, to the slums of the big cities, to the gaols, to the lunatic asylums. Those that once had happy, though frugal, homes. And they and their children degenerate into criminals, into the human drift which parades our streets and cries to you 'a penny sir, for god's sake a penny, to buy shelter or bread.'21

Arthur Richmond is transfixed:

He did not stop to listen for any more it was as if an arrow had pierced his heart and his brain. Oh for mercy sakes, here in his hand he held the fate [of] ... thousands of thousands, for work or to beg rob or steal or worse of all starve. These harmless, still little screws and wires, they could make thousands weep. What for? To enrich himself and a few manufacturers ... Who would be able to enjoy the fresh air, who would be able to improve their homes, their persons and minds, whilst his machine was doing all the work? ... ... The picture in his mind almost

\footnotetext{
combination of socialism and individual liberty, won the enthusiastic assent of all. The book was read and discussed in workshop and on station, in the mining camp and amongst the timber getters, in fact, wherever a few workers were gathered together, there Bellamy was discussed and approved.' Coghlan, quoted in John Sendy, Melbourne's Radical Bookshops: History, People, Appreciation (Melbourne: International Bookshop, 1983), in which there is also an interesting discussion of Andrade's Bookshop and E. W. Cole. For Cole, see also: Ted Turnley, Cole of the Book Arcade (Melbourne: Cole Publications, 1974). Enthusiasm for Bellamy's influence was not unanimous. Another of the McNamaras' correspondents, socialist journalist A. G. Yewen, wrote in 1890 from the Boomerang office in Brisbane: 'I have seen Mabbott, Casey, Seymour \& Lane. They are all well. They are making the A. L. F. [Australian Labor Federation] "hum". The Bellamy gang I have not yet seen, but from what I can gather it is nothing better than a bunch of cranks. They meet and spin cobwebs $\&$ inextricably wind themselves up in the meshes of their own idiocy. Bellamy's book has undoubtedly done good, but if it resulted in nothing better than in the formation of Bellamy societies - Then heaven help us for the Bellamyites won't.' 'A. G. Yewen to W. H. McNamara', 28 December 1890, Evatt Collection.

21 Bertha McNamara, 'For the Good Time Coming', date unknown, unpublished ms, 4, Evatt Collection.
} 
crushed him to the ground. He reached his work-room, he hardly knew how. Here he beheld his wondrous little machine the offspring of long hours of patient study, the result of long hours of toil ... But it was no good to him, he could never use it. Thou (sic) he thought [of] his sweetheart, the pretty home he had pictured as the result of his labour but every note in the prospective [?] was a vail [sic] of human suffering, every thread in the pretty dresses he was going to buy for her to wear was made up of wasted limbs and starved human beings. ${ }^{22}$

Brooding on the choice he has to make, he is visited by his sweetheart, who tells him her brother has given her a book bought at the same rally, Robert Blatchford's Merrie England:

It's such a curious little book and makes it as clear as daylight that we ought not to be poor, not any one of us, and moreover it says, that the Government, or the State, or the people, I don't know which, should own the machinery and the land and all the rest, and give everybody according to his needs, and that everybody should work according to his ability, and that the hours of labour should be regulated according to those labour-saving machines. This is balm to Gilead, my sweetheart he said. We will read it together and learn a great deal of what we ought to know. Even while he was speaking, he had resolved, that his machine should await completion until the conditions where [sic] so altered, that it would become a blessing instead as [sic] a curse to his fellowcreatures. ${ }^{23}$

McNamara concludes with a plea: And now how long my kind readers will he and we have to wait, how long oh people how long? Let us gather together all our strength, all our kindness and our love and work for the good time coming. ${ }^{24}$

Again, it is one of the bestsellers of late nineteenth-century socialism that McNamara urges upon her readers. Blatchford's Merrie England was published in England in 1893. Its impact was immediate, both in Britain and elsewhere in the English-speaking world, and it sold more than a million copies. William Morris, lecturing to the Hammersmith Socialist Society in 1895, attested to the book's importance in Britain:

The thousands who have read that book must if they have done so carefully have found out that something better is possible to be thought of than the life of a prosperous mill-hand ... Self-respect, happy and fit 
work, leisure, beautiful surroundings, in a word, the earth our own and the fullness thereof, and nobody really dares to assert that this good life can be attained till we are essentially and practically Socialized. ${ }^{25}$

Although there appears not to have been an Australian edition of Merrie England, Blatchford joined Bellamy to become one of the two socialist classics to be found in thousands of Australian homes, often alongside a work of the previous decade, Edward Carpenter's prose poem Towards Democracy (1883). I suspect they were read rather more than the works of Marx and Engels. Blatchford and Morris (especially his novel News from Nowhere, published in 1890) have sometimes been interpreted as backward-looking yearnings for a mythical pastoral golden age - symptoms of dislocation and despair rather than agents of change $\mathrm{e}^{26}$ - but here, in the political writings of an Australian socialist and bookseller, Blatchford's book sits alongside Bellamy's as campaigning weapons, as models for a better and fairer society.

Edward Bellamy was not terribly clear on how the transition to the socialist United States of the twenty-first century was to be achieved: it is not revolution he writes about so much as its results. McNamara was clearer, with a consistent line of argument in support of equal suffrage, which begins in the 1891 pamphlet and which continues throughout her political life. In 1891 she supported industrial militancy but not forceful violent revolution. ${ }^{27}$ 'How can each and all of us help to undo the evils of the past and present', she concluded in 1891:

By the ballot-box certainly. By only giving votes to such men, who with a strong voice and hand will abolish plural voting, which gives our large proprietors an undue advantage over the poor man. By only voting men to our Councils of Government, who, with a strong voice and hand put down children's labour, and who instead will give work to the broadshouldered, able unemployed men and the strong young women. To men, who, instead of the factory, will give our children leisure to grow, and our youth, one and all of them an equal liberal education. Neither must we mind rewarding such men liberally, so that their whole time and energy may be devoted to their stupendous work. And, moreover, that fit men will be chosen from the midst of the working classes, who themselves have practically endured the present hardships and unjust treatment of a working man's life. ${ }^{28}$

25 Quoted in E. P. Thompson, William Morris (London: Merlin, 1977), 622.

26 See, for example: Jan Marsh, Back to the Land: The Pastoral Impulse in Victorian England (London: Quartet Books, 1982).

27 For the strike, see: Stuart Svensen, The Shearers' War (Brisbane: University of Queensland Press, 1989).

28 McNamara, Home Talk on Socialism, 8. 
McNamara's advocacy of an effective parliamentary role for working-class representatives (men and elected only by men) was, however, becoming more guarded. Many socialists argued that parliament was only useful as a forum for revolutionary propaganda. The political course adopted by the various Australian labour groups of using their small but useful voting power as a lever for immediate reforms - the tactic denounced by Jutson in his letters to William McNamara - was anathema to such revolutionaries as well. ${ }^{29}$ Social Democracy, as launched by the federation at Sydney Trades Hall on May Day in 1895, brought together in the Second International democratic-socialist and labour thinking that still distrusted Labor parliamentarians but could find a role for them. ${ }^{30}$ McNamara's acceptance of parliamentary activism became more and more conditional, as, for example, in her 1894 pamphlet Commercialism and Distribution of the Nineteenth Century. This advocated

a decentralized form of socialism, where working-class people would create a better society by assuming control of their immediate environment, as producers and as consumers. Only when socialism had already been built up from below would it be safe to direct the state to nationalize the means of production, distribution and exchange-Labor politicians could not be trusted. ${ }^{31}$

In her next published work, the 1908 pamphlet How to Become Rich beyond the Dreams of Avarice in the Shortest Possible Time, published by herself and dedicated to the memory of 'My Dear Husband, William Henry McNamara, who died May 12 '05, and whose life and health were spent in the cause for the emancipation of the world's workers', she continued to urge working-class participation in parliamentary politics. Her main concern, however, was the need for Labor's leaders to return to their socialist roots:

Now surely we ... are not going to perpetuate the Old Order under a new name by substituting desperate struggles between Laborites and Socialists, thus keeping the working class once more asunder, following this or that leader, knowing not whither they are going. Surely it is time for us to take heed of the lessons that history teaches, and, to our utmost ability, prevent the mistakes of our predecessors, for we can hardly plead their ignorance. It is time that with all our might we prevent so dire a calamity as a political struggle between the workers again. It is the people, the poor people, who suffer and are eagerly awaiting the Dawn of the Millennium. ${ }^{32}$

29 See Ian Turner, Industrial Labour and Politics (Canberra: ANU Press, 1965), 21.

30 The ALP today is still a member of the Second International's descendant, the Socialist International.

31 Burgmann, 'McNamara, Matilda Emilie Bertha (1853-1931)', 350.

32 Bertha McNamara, How to Become Rich beyond the Dreams of Avarice; or, Labor \& Socialism (Sydney: [B. McNamara], 1908), 4. 
For the rest of her life, she remained militant both in her views and in the books she sold. ${ }^{33}$ In 1928, campaigning for senate preselection, she argued:

I have from my earliest recollection held the strong conviction that it is little use to patch up this hideous social system called Capitalism, and there is little use in patching it with small reforms which chiefly consists (sic) of robbing Peter to pay Paul and makes the rent more hideous still. Financial Reform Abolition of Interest paying and borrowing is the centre from which we have to start, all other things required and desired being around it such as proper housing, proper food, proper medical attendance and proper Education. ${ }^{34}$

'If all our Labor Traitors had been true to the cause' in parliament, she asked in 1924, including her erstwhile customer Billy Hughes,

how much further we would be to Social Reconstruction by now. How much misery there would have been saved in the world. Even the capitalistic World-War would never have taken place. Labor, Socialism and Communism has no time or place for Wars [in] its objects of Cooperation and Justice for all men. 60,000 young Australians would now be enriching their beloved land instead of nurturing the soil of Europe and elsewhere with their dead bodies and mountains of heartbreaks and oceans of tears would have been spared to the loved ones of home. Think of this you Judas Iscariots what you have got to answer for ... Well will it be if they [the working classes] will not be deluded by the Capitalist orators and press. The lambs to lie down with the Lion. Well they ought to know by this what the Lion has done with the Workers for thousands of years, made slaves of them and will ever do so if they may, wether [sic] it be chattel slaves or wage slaves. ${ }^{35}$

So should we take much notice of Bertha McNamara? Much in her political rhetoric was common to the era. Is she simply an interesting example of a politically motivated immigrant who overcame the difficulty of her poverty, published some interesting pamphlets and was a conduit to a world of ideas and activism for her circle? I would argue that she matters, in part because of her commitment to women's rights and women's leadership. This is clearly articulated in a 1928 address at the Pyrmont Workers Centre:

\footnotetext{
33 McNamara's bookshop in Castlereagh Street was mentioned in the Sydney Sun in 1922, at a time when it was about to be demolished. It was described then as 'The Bookshop of Isms! It is a familiar resort in Castlereagh-street, this depot of terrific literature. All sorts of cheerful foreign gentlemen and amiable conspirators have stalked in and out of its little, narrow door in the years when anarchy was a hobby of much the same calibre as chess or dominoes.' Sydney Sun, 29 December 1922. I am indebted to the late John Holroyd for this pre-Trove reference.

34 Bertha McNamara, 'Preselection circular to ALP members', 1928, unpublished ms, Evatt Collection.

35 'Letter to Labour Daily', c. 1924, unpublished ms, Evatt Collection.
} 
That women should receive an equal chance with men in the Councils of Social Welfare, they as well as the men have to live under the law are responsible to the law and have to bear the burden equally with the men and especially as concerns the workers wives often more so, industrially as well as in personal home affairs. Therefore they should equally share in the making of laws. ${ }^{36}$

And in her Manifesto to All Laborites seeking senate preselection, also of 1928, she was unequivocal in her demand that women should be elected to parliament, based on their equal share in the struggle for social justice:

As the unanimously chosen representative of the Labor women of this State, I appeal to you, both men and women, particularly Unionists, to remember that whatever standards of relative comfort you have today are the result not only of the fight, politically and industrially, of our men, but also of our women. Woman has shown, not only as an active Unionist in those callings to which capitalist economics has forced her; not only as a militant propagandist in local A. L. P. branches and at elections, but also as a fellow-sufferer and fellow-fighter during the strikes and lock-outs that have been forced on Labor, that she must share the burden of the battle for a better system.

If that is so, how can you then deny woman a share in the administrative and executive work of Labor?

To do so is to ask of woman all, and to concede her-nothing; nothing but the toil and moil; it is to look upon her not as a help-mate and comrade, but as a drudge and slave. ${ }^{37}$

It was not her own history of loyalty to the party that should count with preselectors, she argued, but rather '[t] he duty that you as Unionists and Laborites owe to your women-folk; to your mothers, your wives, your sisters, your fellow-sharers of the privations of the battle for a better social system ...A Vote for WOMAN is a Vote for PROGRESS' ${ }^{38}$

She was appealing to deaf ears: it was not until 1943 that a Labor woman entered the Senate, when Dorothy Tangney won endorsement high enough up the ballot paper to be elected from Western Australia. Instead, McNamara was marginalised to the safe role of 'Mother of the Movement'.

36 Bertha McNamara, 'Pyrmont Centre of Workers', 1928, Unpublished ms, Evatt collection.

37 Bertha McNamara, 'Manifesto to all Laborites/Particularly All Unionists of N.S.W. from Mrs. Bertha McNamara (Sydney: Labor Daily, 1928)', one-page ephemeron, emphasis original, Evatt Collection.

38 Ibid. 
I have discussed Bertha McNamara as a bookseller, a socialist and as a feminist. What was she like as a person? That she was a forceful speaker and writer is clear. Here, for example, is a brief passage entitled 'Crucified Again', denouncing the diplomatic representatives at the Hague Convention of 1907: 'This lickspittle Royalist, Lawyer, Usurer crew who pretend they want to promote peace, whilst at the same time they are upholding and defending the pernicious ... Kingcraft, Priestcraft, Usury, the Worship of the Golden Calf all of which leads to strife and makes war almost a necessity. ${ }^{39}$ But she had a gentler side. In a loving reminiscence of her, Clarice McNamara, one of her daughters-in-law, spoke of her first visits to McNamara's bookshop:

No picture in my memory could be clearer than those overcrowded shelves bulging with lively books and journals, and behind the counter the compelling personality of the little proprietress. No-one who did not know her would have guessed, from her sparkling periwinkle-blue eyes, her beautiful skin and soft white hair and her general air of maternal tenderness mixed with a lovely sense of fun, that this was one of the most dogged fighters for human rights and social justice in the history of Australian politics. ${ }^{40}$

And in a letter to her husband, William McNamara, written in 1894, something of the indomitable spirit of Bertha McNamara can be glimpsed. He was in prison, serving a six-month term for selling a newspaper, Hard Cash, which had libelled a financial corporation during the great bank crashes of the 1890s that wiped out the savings of thousands of Australian families:

My dear Willy I can see you are anything but happy, make your mind easy, eat, drink, sleep and be merry so as to be strong and well when you come home to work for us and the dear baby ... I was watching all last this week for a possible chance to send you some books but not one occured so ? I will send Hilda next week and send books and the other few articles you mention. Its impossible for me to carry baby and the parcels or else you should not have to wait for them. It is equally

\footnotetext{
39 Bertha McNamara, 'Crucified Again', 1907, unpublished ms, Evatt Collection.

40 Clarice McNamara was herself a life-long activist. A public schoolteacher, she discovered she had been sent to the countryside by the Education Department at the beginning of her career to get her away from radical associations. She wrote for Workers Weekly as Ann Scarlitt and was active in the Militant Women's Group (associated with the Communist Party of Australia) in the 1920s. She later refused an offer of secret membership of the party and with her husband, William (Bill) McNamara, took the Labor side in the disputes of the 1930s and later, 'owing to my complete disillusionment about the Soviet dictatorship with its subsequent terrible purges and trials and killings of dissidents, together with my reading of Trotsky's moving autobiography'. She was also active in the New Education Fellowship, a progressive educational reform movement founded in the United Kingdom in 1921, and was a close friend of Mary Alice Evatt. Clarice McNamara, 'Trailing the Twentieth Century', Unpublished autobiography in the McNamara family papers, courtesy of Margaret Bertha McNamara Henry, 133. See also Audrey Johnson, Bread and Roses (Sydney: Left Book Club, 1990), 9-27.
} 
impossible to leave him at home when I do come as it takes the best part of a day and he is so mischievous it takes just all of us to mind him, excepting while he sleeps and that is not much ... Your father wrote another very kind letter ... and said he would forward some assistance later on. We received some money which had been collected on the Yarra. Don't fret or trouble about going into the other Gaol you may rest assured that this will not happen while there is anyone to help. ${ }^{41}$

I have sketched Bertha McNamara's career, and discussed her political views, as expressed in surviving manuscripts and rare pamphlets. I have suggested the importance of literary inspiration to her in modelling alternatives to the misery and despair she encountered, in both the poverty that dogged her own life at every turn and in the larger poverty of economic depression. Political views formed in the 1880s and 1890s, through the worst depression and political turmoil known to white Australia up to that time, remained the source of her hope for the future when the country again encountered despair and economic recession in the late 1920s. As a bookseller, as a gatekeeper for radical thought in Sydney and beyond, from the 1890s to the late 1920s, she is a figure of significance in Australian political history, and one who contributed to the growth of new models of feminist leadership.

The Museum of Australian Democracy entered into the 'Women and Leadership' project in order to learn more about how to approach the task of telling the story of women in Australian democracy, and in order to support the collection of the material evidence of women's leadership. Although some have criticised the museum for an apparent focus on the displacement of the politics of redistribution by the politics of recognition' ${ }^{42}$ in our exhibitions, it is surely the case that the extension of political rights to women is an important story per se. The challenge in a museum is to tell a story that is anchored in holdings and displays of relevant material culture. As my colleague Libby Stewart has shown, the museum has been more successful in doing this with regard to the British suffrage experience than that of Australia. The material culture is fugitive, ephemeral and scarce. As yet there is little of it in the collection, although it is a high priority.

In an insightful keynote address to the Museums Australia Conference in Perth in 2011, Ross Gibson suggested that a museum might be a keeping place for feelings as well as meanings, a place where the systems of feelings that motivate people, and the key shifts in their shape, could be explored. ${ }^{43}$ How could we

\footnotetext{
41 'Bertha McNamara to William McNamara', 27 April 1894, Evatt Collection.

42 Marian Sawer and Peter Brent, 'Equality and Australian Democracy', Democratic Audit Discussion Paper, October 2011, 28, http://democraticaudit.org.au/wp-content/uploads/2009/03/sawer_brent2011.pdf.

43 Ross Gibson, 'Systems of Feeling', Keynote address to the Museums Australia Conference, Perth, 18 November 2011.
} 
create a 'sense of readiness' among museum visitors to experience the huge shift in thinking of people like Bertha McNamara a century and more ago as they demanded the apparently impossible: a place in the parliament, at the heart of the governing of Australia? Is material culture from the past enough, especially when the material evidence of political life is so ephemeral?

Professor Gibson asked how we might bring aesthetics into interplay with the semantic, a theme addressed also by Andrea Witcomb in interrogating memorials. ${ }^{44}$ I have sometimes wondered whether a possible starting point might be to introduce a group of women into King's Hall as partners in a conversation with the bronze bas-reliefs of the parliamentary 'Founding Fathers' who have gazed from its columns since 1927. They could also mirror and challenge George V, who has also been there since 1927. This is what our highly successful museum theatre project for the Centenary of Federation, 'The King's Hall 9', did in 2001. This brought Catherine Helen Spence, Muriel Matters and Jessie Street (also an unsuccessful Labor candidate for a seat in this House) into King's Hall and the Chambers.

I think (and this is purely a personal view and has no endorsement by the museum) representation of the women who first stood for Federal Parliament, and some of those who first tried to break the barriers into this building, whether endorsed by their party or not, could also help bridge the gap between Australian political history before 1927 and the heritage significance of old Parliament House. Thus visitors would meet Mary Moore-Bentley, one of the four women who stood for parliament in 1903, who won the largest number of votes for a female candidate in New South Wales - 18,924 - and who wrote a feminist science fiction novel, A Woman of Mars; or, Australia's Enfranchised Woman. ${ }^{45}$ They would meet Vida Goldstein, who openly spoke of an ambition to be prime minister, who won 51,497 votes in Victoria in 1903, and who stood again four more times between 1910 and $1917 .{ }^{46}$ With her would stand Nellie Martel, advocate for equal pay, who won the support of 18,502 voters for the Senate in 1903; ${ }^{47}$ and Selina Anderson, trade unionist and the first woman to

\footnotetext{
44 Andrea Witcomb, 'Using Immersive and Interactive Approaches to Interpreting Traumatic Experiences', Keynote address to the Museums Australia Conference, Perth, 17 November 2011.

45 Mary Moore-Bentley, A Woman of Mars; or, Australia's Enfranchised Woman (Sydney: Edwards, Dunlop, 1901). See also entry for 'Mary Ling' (her married name), in Margaret Bettison, 'Ling, Mary (1865-1953)', in Australian Dictionary of Biography Online (Canberra: National Centre of Biography, The Australian National University), http://adb.anu.edu.au/biography/ling-mary-13048/text23595.

46 Janice N. Brownfoot, 'Goldstein, Vida Jane (1869-1949)', in Australian Dictionary of Biography Online (Canberra: National Centre of Biography, The Australian National University), http://adb.anu.edu.au/ biography/goldstein-vida-jane-6418/text10975.

47 Margaret Bettison, 'Martel, Ellen Alma (Nellie) (1855-1940)', in Australian Dictionary of Biography Online (Canberra: National Centre of Biography, The Australian National University), http://adb.anu.edu.au/ biography/martel-ellen-alma-nellie-13081/text23663.
} 
stand for the House of Representatives, who secured 18 per cent of the vote in Dalley and who in 1908 (as Selina Siggins) was one of the first women to stand for the SA Legislative Assembly. And they might also meet Bertha McNamara.

The Museum of Australian Democracy embraced this Australian Research Council project because the museum saw it as being about helping it and other like institutions to devise better ways of interpreting the story of women and leadership for visitors, onsite and online, as well as being about improving understanding of what museums can and should collect to represent that theme. What could museums do to better explore it, in ways that are historically sound and fiscally prudent, but also imaginative, creative and able to speak to a wide range of visitors, many of whom know nothing of the background? This too will need 'all our strength, all our kindness and our love'.

\section{References}

Bettison, Margaret. 'Ling, Mary (1865-1953).' In Australian Dictionary of Biography Online. Canberra: National Centre of Biography, The Australian National University. http://adb.anu.edu.au/biography/ling-mary-13048/ text23595.

Bettison, Margaret. 'Martel, Ellen Alma (Nellie) (1855-1940).' In Australian Dictionary of Biography Online. Canberra: National Centre of Biography, The Australian National University. http://adb.anu.edu.au/biography/martelellen-alma-nellie-13081/text23663.

Brownfoot, Janice N. 'Goldstein, Vida Jane (1869-1949).' In Australian Dictionary of Biography Online. Canberra: National Centre of Biography, The Australian National University. http://adb.anu.edu.au/biography/goldsteinvida-jane-6418/text10975.

Burgmann, Verity. 'In Our Time': Socialism and the Rise of Labor, 1885-1905. Sydney: George Allen \& Unwin, 1985.

Burgmann, Verity. 'McNamara, Matilda Emilie Bertha(1853-1931).' In Australian Dictionary of Biography Online. Canberra: National Centre of Biography, The Australian National University. http://adb.anu.edu.au/biography/mcnamaramatilda-emilie-bertha-7431/text12935.

Burgmann, Verity. 'McNamara, William Henry (1857-1906).' In Australian Dictionary of Biography Online. Canberra: National Centre of Biography, The Australian National University. http://adb.anu.edu.au/biography/mcnamarawilliam-henry-7432/text12937. 
Burgmann, Verity. 'In Our Time': Socialism and the Rise of Labor, 1885-1905. Sydney: George Allen \& Unwin, 1985.

Evatt Collection. Special Collections. Flinders University Library, Adelaide.

Gibson, Ross. 'Systems of Feeling.' Keynote address to the Museums Australia Conference, Perth, 18 November 2011.

Government of Australia. Women in the Senate. Senate Brief 3. Canberra: Department of the Senate, April 2014.

Johnson, Audrey. Bread and Roses. Sydney: Left Book Club, 1990.

McNamara, Bertha. How to Become Rich beyond the Dreams of Avarice; or, Labor \& Socialism. Sydney: [B. McNamara], 1908.

[McNamara, Bertha]. Home Talk on Socialism, and the Redemption of the World's Labourers. Hobart: Calder, Bowden \& Co., 1891.

McNamara, Clarice. 'Trailing the Twentieth Century.' Unpublished autobiography in the McNamara family papers, courtesy of Margaret Bertha McNamara Henry.

Marsh, Jan. Back to the Land: The Pastoral Impulse in Victorian England. London: Quartet Books, 1982.

Mellor, W. H. Manifesto of the Social Democratic Federation of Australasia. Sydney: The Federation, 1895. MS 9547, Box 1268/5, State Library of Victoria, Melbourne. http://www.reasoninrevolt.net.au/biogs/ E000042b.htm.

Moore-Bentley, Mary. A Woman of Mars; or, Australia's Enfranchised Woman. Sydney: Edwards, Dunlop, 1901.

Sawer, Marian and Peter Brent. Equality and Australian Democracy. Democratic Audit Discussion Paper, October 2011. http://democraticaudit.org.au/wpcontent/uploads/2009/03/sawer_brent2011.pdf.

Sendy, John. Melbourne's Radical Bookshops:History, People, Appreciation. Melbourne: International Bookshop, 1983.

Svensen, Stuart. The Shearers' War. Brisbane: University of Queensland Press, 1989.

Sydney Sun, 29 December 1922.

Thompson, E. P. William Morris. London: Merlin, 1977. 
Diversity in Leadership: Australian women, past and present

Turner, Ian. Industrial Labor and Politics. Canberra: ANU Press, 1965.

Turnley, Ted. Cole of the Book Arcade. Melbourne: Cole Publications, 1974.

Witcomb, Andrea. 'Using Immersive and Interactive Approaches to Interpreting Traumatic Experiences.' Keynote address to the Museums Australia Conference, Perth, 17 November 2011. 
This text taken from Diversity in Leadership: Australian women, past and present, edited by Joy Damousi, Kim Rubenstein and Mary Tomsic, published 2014 by ANU Press, The Australian National University, Canberra, Australia. 